\title{
Quantitative Easing: New Normal or Emergency Measure?
}

Piotr Bartkiewicz

ABSTRACT This article explores the economic justification of the use of unconventional monetary policy instruments such as asset purchase programmes (known as quantitative easing, QE) with the aim of assessing the nature of QE in the context of future monetary policy in Poland. Since 2008, numerous asset purchase programmes have been launched by central banks in major developed economies to raise economic growth and inflation in the aftermath of the Global Financial Crisis. These programmes can be seen either as part of broader, longer trends (demographic, socioeconomic) or as an emergency measure (i.e. a response to unique circumstances). The former hypothesis calls on central banks to treat unconventional monetary policy instruments as a necessary part of their toolbox, while the latter implies that QE is unlikely to be used again in the future. Drawing from a wide set of macroeconomic data and a proprietary literature review, I describe the macroeconomic context for unconventional monetary policy, present arguments for both paradigms and their implications. I conclude that recent developments favor the former hypothesis and that this debate will most likely be settled within several years and can be informed by business cycle developments in major developed economies.

KEY WORDS: $\quad$ monetary policy, quantitative easing, central banks, global financial crisis

JEL Classification: E52, E58.

SGH Warsaw School of Economics, Poland

\section{Introduction}

Since 2008, central banks in most major developed economies have launched extensive asset purchase programmes whose goal was to increase the degree of monetary accommodation beyond what could be achieved by reducing short-term nominal interest rates to near-zero (or, later on, even negative) levels. Such programmes have had different designs, sizes and stated aims, but all have received a common name: quantitative easing (QE) (for early uses of the term see: (Ito, 2006; Shirakawa, 2001; Spiegel, 2001;)). More general terms, "non-standard monetary policy" or "unconventional monetary

Correspondence concerning this article should be addressed to: Piotr Bartkiewicz, SGH Warsaw School of Economics, Poland. E-mail: bartkiewicz.p@gmail.com policy", refer to a broader suite of instruments, including negative nominal interest rates and lending to financial institutions (Joyce, Miles, Scott \& Vayanos, 2012). After nine years, the asset purchase programmes led to a sizeable increase in central bank assets and, working through various channels, eased financial conditions, raised output and inflation (Bernanke, 2012; Krishnamurthy \& VissingJorgensen, 2011, 2013; Żywiecka, 2013). Thus, central banks have become major holders of public debt securities and other financial assets, influencing their prices via flow and stock effects (D'Amico \& King, 2013). Since the beginning of the current period of unconventional monetary policy, there has been considerable debate regarding the uniqueness of post-2008 central bank policy. For some authors (Yellen, 2015, 2017), QE is unlikely to be launched 
by central banks again in the future and the degree of monetary accommodation demanded by next recessions will be smaller than in 2008-2009. Alternative view (often dubbed as "new normal" - (Summers, 2013)) stems from the belief that long-term trends present in major developed economies will continue to reduce the effectiveness of standard monetary policy and that monetary easing achieved by cutting nominal interest rates will not be enough even in standard recessions.

There are several reasons this issue might be of interest to private and public agents. First, central banks themselves must understand the rationales for their policies and allocate resources to execute them and study their effects. Second, QE influences the economy and specific economic actors in multiple ways. If it is to become a part of the standard monetary policy toolbox, actors must consider its possible negative side effects. Finally, the uniqueness of post-2008 monetary policy is relevant to Poland as well. If the "new normal" hypothesis is true, the secular trends that led to the launch of asset purchase programmes apply to Polish economy as well. This, in turn, suggests that the National Bank of Poland, despite conducting a completely conventional monetary policy to date, may one day be forced to use non-standard monetary policy instruments. This possibility was admitted by NBP officials on several occasions (NBP, 2019a, 2019b). According to the NBP governor, an internal review of available instruments and their suitability was prepared by the staff. It was motivated precisely by concerns that conventional monetary easing might not be enough to respond to all negative shocks that might occur in the future.

The aim of the study is to identify whether QE is an emergency response to the exceptional challenge posed by the Global Financial Crisis (GFC) or a new normal, i.e. standard tool for central banks that will be used in the future. The former would imply that QE is not destiny and that standard monetary policy in countries like Poland will continue to be effective in the foreseeable future. The latter, on the other hand, suggests that the pre-GFC status quo in monetary policy cannot be returned to and that policymakers must take the inevitability of QE into account.

\section{Evolution of Monetary Policy and its Macroeconomic Fundamentals since the GFC}

Monetary policy has evolved considerably over the past decades, but a broad consensus emerged in the 1990s. Three key features of modern monetary policy can be identified: the inflation target, institutional independence of the central bank and use of shortterm nominal interest rate as the primary instrument of monetary policy (Sławiński, 2011). The inflation target is typically defined as an annual growth rate of a consumer price index (usually in the $2.0-2.5 \%$ range) and is either a single medium-term goal or part of a dual mandate. The existence of a nominal anchor in the form of such target is seen as important signal for economic agents and amount of inflation optimal in economies with nominal rigidities and shocks impacting relative prices (Woodford, 2003). Institutional independence has become law in most countries and is often ensured by the existence of a committee separate from central bank management, whose task is to make monetary policy decisions. Finally, the short-term interest rate has become the sole instrument of monetary policy after the unsuccessful attempts at money supply targeting (Friedman \& Kuttner, 1992). The emergence and use of this triad coincided with a period of stable economic growth and unusually low macroeconomic volatility, known as the Great Moderation (Bernanke, 2004).

Prior to the GFC, unconventional monetary policy was mostly a theoretical possibility. Nevertheless, the challenges facing monetary policy if nominal interest rates fall to zero, were given serious consideration (Eggertsson \& Woodford, 2003; Fuhrer \& Madigan, 1997; Krugman, Dominquez \& Rogoff, 1998; Summers, 1991). Additionally, several historical precedents were known to researchers: (1) experiments with treasury bond purchases during the Great Depression (Bordo \& Sinha, 2016); (2) wartime control of short-term and long-term interest rates via central bank purchases of Treasury debt (Youngman, 1945); (3) Japan's experience since the 1990s (Krugman et al., 1998). The latter was particularly prescient: Bank of Japan (BoJ) cut interest rates to zero in April 1998 (BoJ, 1998, 1999) and began its purchases of Treasury bonds in 2001 (BoJ, 2001). The experience of Japan was, however, often believed to be unique and inconsequential for other developed economies (Krugman et al., 1998). 


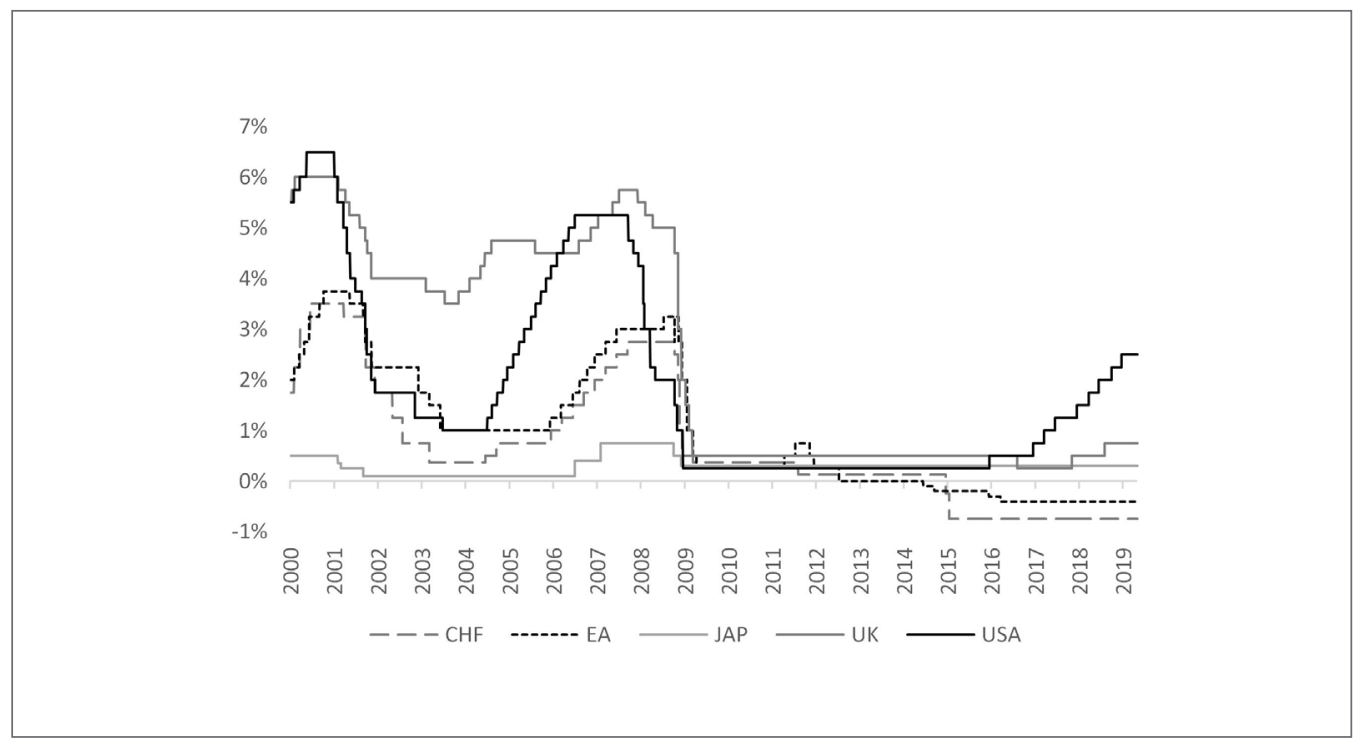

Figure 1. Key interest rates of major central banks.

Source: own elaboration based on FRED, ECB, BoE, BoJ and SNB data.

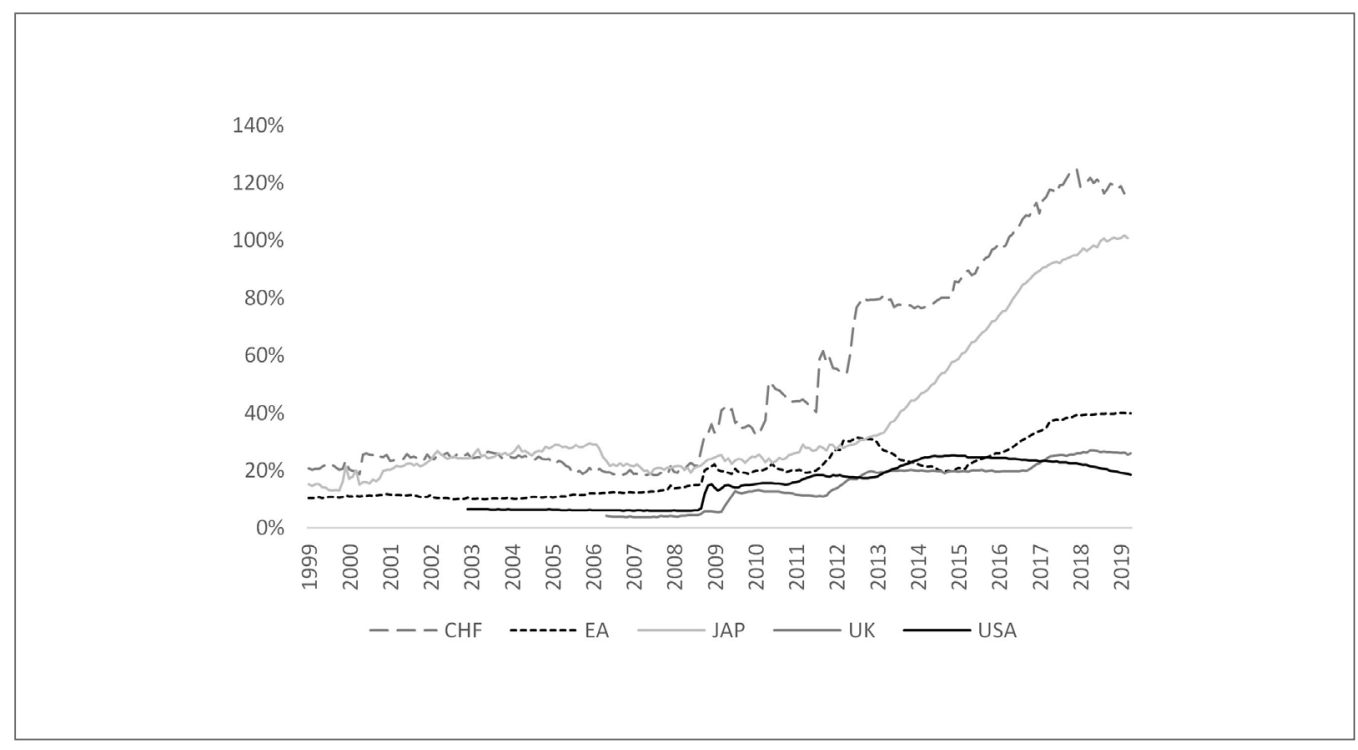

Figure 2. Assets of major central banks as \% of GDP.

Source: own elaboration based on data from FRED, ECB, SNB, BoE, BoJ, Eurostat and OECD. 
The recession of 2007-2009 (its timing varies between countries by several months) was the deepest and longest one since the 1930s, and was also associated with severe financial stress and a banking crisis (Reinhart \& Rogoff, 2009). The full extent of the recession has not been apparent until it was well advanced - public and private forecasters saw a mild recession even in late 2008. For instance, private sector forecasts for the US economy made throughout 2008 underestimated the depth of the recession by several percentage points (cf: Survey of Professional Forecasters compiled by the Reserve Bank of Philadelphia or the Wall Street Journal's Forecasting Survey), while the European Central Bank (ECB) projected a relatively mild recession as late as in December 2008 (ECB, 2008). As a result, at the turn of 2008 and 2009 all major central banks cut interest rates to zero or close to zero: on December 16th the Federal Open Market Committee (FOMC) set the target for the federal funds rate at $0-0.25 \%$ (Board of Governors of the Federal Reserve System [FRB], 2008b); the ECB lowered its reference rate to $0.5 \%$ in May 2009 (ECB, 2009); the Bank of England (BoE) ended its series of rate cuts in on March 5th, at $0.5 \%$ (BoE, 2009b); the Bank of Japan cut its main rate to $0.1 \%$ on December 19th (BoJ, 2008); the Swiss National Bank (SNB) rates hit zero on March 9th (SNB, 2009). Thus, in the middle of the Great Recession, all major central banks lost their ability to increase monetary accommodation via standard instruments (Żywiecka, 2013).

QE hit media headlines on November 25th 2008, when the Federal Reserve (Fed) announced that it would buy $\$ 100$ bn of bonds of government-sponsored enterprises (GSEs) and \$500 bn of mortgage-backed securities (MBS) (FRB, 2008a) - the programme would later become known as QE1, but at the time of its inception it was thought of as an emergency measure (Bernanke, 2012). The slow recovery after the recession led Fed to launch two additional rounds of QE: QE2 was announced on November 3rd 2010 (FRB, 2010), QE3 was announced on September 13th 2012 (FRB, 2012). In addition, Fed also altered the composition of its balance sheet via the so called "Operation Twists", in which short-term Treasuries were swapped for longterm Treasury bonds (FRB, 2011). Total Fed assets peaked at $25 \%$ of GDP in late 2014 , after which the purchases were gradually wound down. Beginning in
2018, the Fed allowed its security holdings to decline in current dollar terms by limiting reinvestment of coupons and principals from maturing papers (FRB, 2017). BoE launched its own programme, initially concerning private assets and financed with shortterm Treasury bills, on January 21st 2009 (BoE, 2009a). The BoE meeting of March 4th-5th brought a change in QE's setting - it was remodelled after the Fed's programme as direct purchases of Treasury debt on the secondary market (BoE, 2009b). The programme was restarted on two occasions: on October 6th 2011 (BoE, 2011) and August 3rd 2016 (BoE, 2016). SNB's actions focused on FX interventions (SNB, 2009) and thus even though the bank has never bought domestic financial assets, its balance sheet expanded more than any other central bank and is still growing (Żywiecka, 2013). FX interventions were also the preferred instrument for the Czech central bank (CNB, 2013). BoJ restarted its asset purchase programme in 2011 (BoJ, 2011) and has expanded it and modified extensively on numerous occasions. Notably, in 2013 its asset purchase programme was tied to an explicit goal of permanent increase in the monetary base - a commitment no other central bank has undertaken to date (BoJ, 2013; Ciżkowicz, 2012). ECB launched its own QE programme on January 22nd 2015 (ECB, 2015), but the programme must be seen as a culmination of a cornucopia of various emergency lending and purchase programmes in 2009-2014 (Bednarczyk, 2015; Bluwstein \& Canova, 2016). After several alterations to the size and the composition of the QE programme, ECB assets have continued to grow since 2015, albeit its pace was gradually reduced starting from 2017. Also, in 2015, the Sveriges Riksbank initiated its own asset purchases, focused on government bonds (Riksbank, 2015)

It is worth noting that QE programmes have taken different forms over the past years and varied in size, duration, composition and declared limits. On one hand, most major central banks purchased local Treasury bonds and this type of financial asset (due to its liquidity, heterogeneity and the role of yield curve for economic agents) continues to be the most numerous of all among central bank assets - in some cases central banks have become important holders of public debt securities. On the other hand, BoJ, ECB and BoE experimented with buying private 
assets: investment-grade corporate bonds, ETF shares, asset-backed securities (ABS) and covered bonds. The Federal Reserve's MBS purchases are directly analogous to those. Initially, all QE programmes have been declared as fixed-size (total value of purchases known in advance). However, recent programmes have been described as open-ended (the case of BoJ's purchases since 2013) or conditional (Fed's QE3 was tied to unemployment rate, ECB's QE programme - "until the Governing Council sees a sustained adjustment in the path of inflation consistent with its inflation aim" (Draghi \& Constancio, 2016)). The SNB's commitment to unlimited FX interventions resembles QE in its open-ended form.

\section{The Case for „New Normal”}

The first of the two interpretations of QE outlined in the Introduction is "new normal" - the idea that QE (and other unconventional monetary policy measures to which a lot of the same considerations apply) should be treated as an instrument typically used by central banks to influence aggregate output and inflation. The increased reliance on QE is supposed to be a direct result of long-run trends in interest rates and other economic variables (Summers, 2014a, 2014b). It is worth noting that the prevalent view among academics and central bankers is that unconventional monetary policy should remain part of central banks' toolkit (Blinder, Ehrmann, De Haan \& Jansen, 2017). However, the popular interpretation of future necessity of using QE is likely to be primarily shared by private sector economists and journalists.

\subsection{Long-term Trends in Short and Long-term Interest Rates}

Long-term trends in interest rates are typically used as a most potent illustration of the new normal hypothesis (Desroches \& Francis, 2006). However, it must be noted that in any given economy there are multiple interest rates: short- and long-term; central bank, interbank, retail credit and deposit rates; nominal and real; Treasury bond yields and yields on private securities of varying credit quality. I limit our analysis to just two types of interest rates: short-term (3-month) interbank rates and long-term (10-year) government bond yields. Both are benchmarks for two extremes of the yield curve and remain unaffected by liquidity or market segmentation issues. Furthermore, over multi-decadal horizons, interest rates of intermediate tenors behave similarly. In addition, all interest rates exhibit cyclical and trend behaviour - it is important to distinguish the two.

Having risen since World War II, short-term interest rates peaked at the turn of 1970 s and 1980 s - this is associated with restrictive monetary policy conducted by major central banks in the wake of inflationary episode of the 1970s (Sargent, 1999). Subsequent changes in interest rates varied across major developed economies (see Figure 3), but the general pattern of lower cyclical peaks and lows have held since 1980 in all analysed countries. To put it differently, each subsequent monetary tightening episode ended at a lower level than the previous one and, conversely, each time monetary policy was eased, short-term interest rates bottomed lower than in the previous episode. The drop to zero at the turn of 2008 and 2009 must thus be seen as a logical consequence of this trend. For long-term interest rates the pattern is even clearer as their cyclical behaviour is far less pronounced than for shortest interest rates. In general, 10-year nominal interest rates declined considerably, from 15-16\% in 1983 to $0-2 \%$ in recent years.

While nominal interest rates are directly observable and perceived by economic agents, economists are often interested in real interest rates as well, as these are more tractable in theoretical models and offer other opportunities for interpretation. There is, however, no universally agreed upon method of calculating real interest rates - expected inflation can be approximated using surveys of households, enterprises or professional forecasters, as well as derived from financial market instruments. However, regardless of methodology, the downward trend in real interest rates, especially long-term ones, is still evident. Thus, multi-decade trends in nominal interest rates cannot be explained by disinflation alone. It is also worth noting that macroeconomic theory and modern monetary policy typically (Laubach \& Williams, 2016; Yellen, 2017) distinguishes between the actual and equilibrium real interest rates - in such a setting the former is set by the cen- 


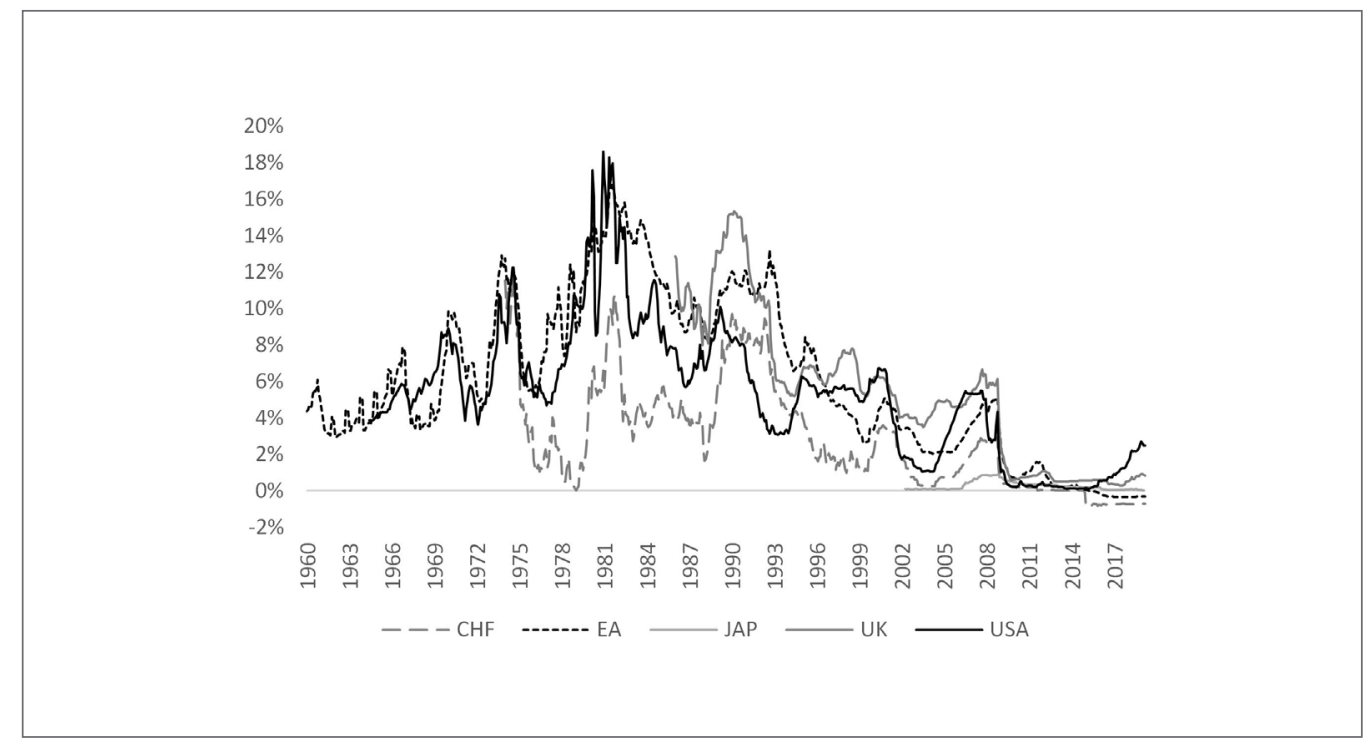

Figure 4. Evolution of long-term interest rates (10-year constant maturity government bond yields) in selected economies. Source: own elaboration based on OECD MEI database.

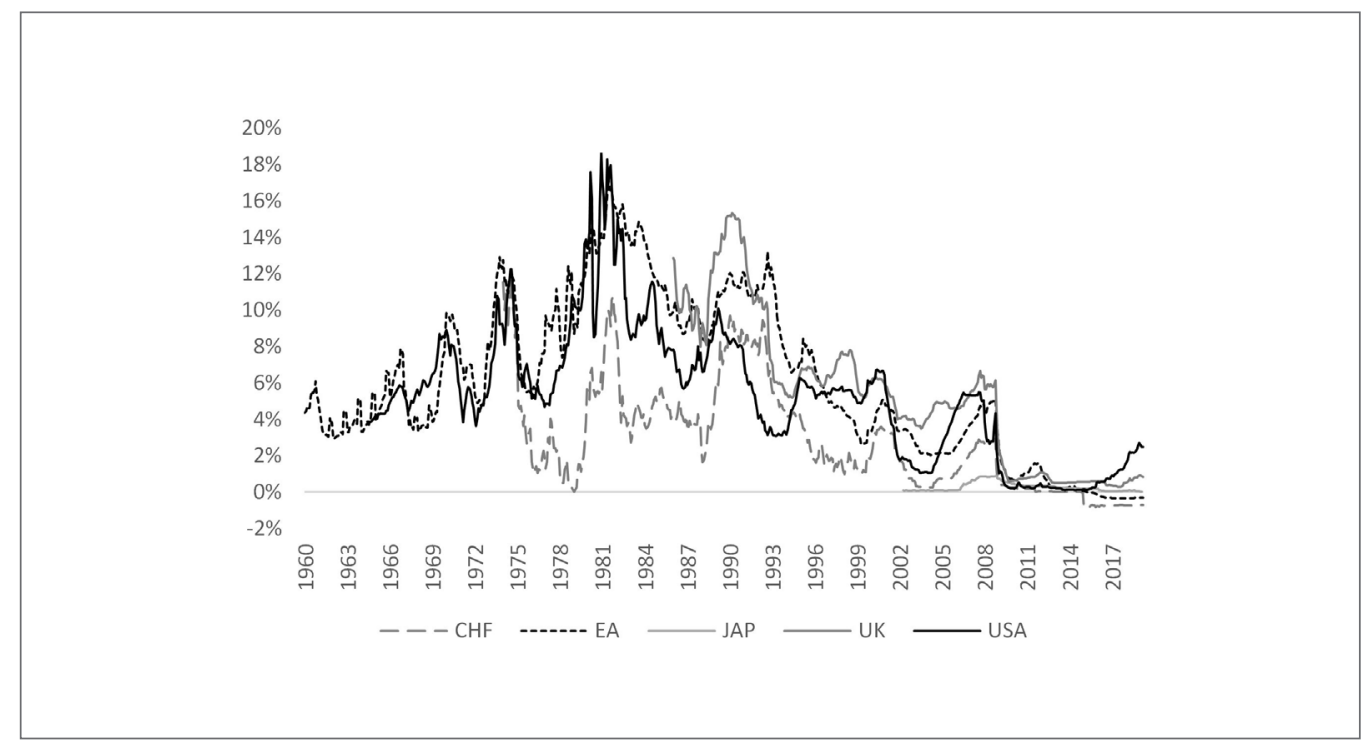

Figure 3. Evolution of short-term (3-month) interbank interest rates in selected economies.

Source: own elaboration based on OECD MEI database 
tral bank (up to a limit, as the central bank's control over real variables is far from perfect), while the latter reflects underlying structural factors. The difference between the two rates is therefore seen as a measure of monetary policy stance: the lower the actual real interest rates relative to the equilibrium rate, the looser monetary policy is (Yellen, 2017). Furthermore, similar patterns are observed across a broad set of macroeconomic variables: interest rates, inflation, productivity and GDP per capita growth (Gordon, 2012).

\subsection{Possible reasons for the observed trends}

Several explanations for the above-mentioned trends have been proposed (Eggertsson \& Mehrotra, 2014; Eichengreen, 2014).

Firstly, they are often associated with demographic change in developed economies. These are said to influence interest rates via at least two channels: (1) by reducing working age population growth and, holding other factors constant, labour force growth relative to total population growth, they drag down potential output growth and potential per capita growth; (2) due to the well-known patterns in life-cycle consumption and income accumulation (individuals earn income while being economically active, with life-cycle peak at approx. 40; consumption declines in the run-up to and after retirement, but obviously cannot reach zero), changes in population structure influence aggregate saving and the balance between demand for financial assets and their supply. For example, Japanese working age population peaked earlier than in all other developed economies and this demographic turning point was followed by a period of low aggregate GDP growth, exceptionally low inflation or outright deflation and very low nominal interest rates. In addition, Japanese experience is often said to foreshadow other developed economies as Japan's late 1980s asset bubble and the subsequent financial crisis resembles the U.S. subprime bubble and subsequent financial disturbance to some extent (Mikitani \& Posen, 2000).

Secondly, the downtrend in interest rates is often associated with changes in the global economy, merchandise trade and international division of labor that are typically described as globalization.
Since 1980 trade and capital flows have been greatly liberalized and their growth far outstripped global GDP growth. At the same time, several large economic blocks (China, India and other Eastern and Southern Asian countries, the former communist states in Eastern Europe) were inducted into global value chains and sharply increased their openness. As a result, a large pool of comparably cheap labor became available at the time the global economy had become ready to take advantage of it. The subsequent wave of off-shoring and building international supply chains might have contributed to the downward pressure on interest rates, but conceivably the biggest impact of these processes has occurred for the prices of tradables, thereby structurally shifting inflation downwards.

Thirdly, the downward trend in nominal interest rates is often associated with global imbalances, i.e. the existence of large and persistent current account surpluses and deficits, by definition mirrored by large and persistent unidirectional capital flows. Measured by value, United States is the single largest deficit country (1.0-1.5\% of world GDP), followed by the United Kingdom and southern Euro area (EA) countries. Global surpluses are evenly split into three categories: oil exporting countries, developed surplus countries (Germany and Japan), China and other emerging East Asian economies (IMF, 2017). Regardless of the source of the imbalances (whether savings-investment balance is affected by policies in surplus or in deficit countries), the downward pressure on interest rates is a result of demand for U.S. Treasury securities issued by reserve managers in surplus countries. By definition, current account surplus is equivalent to a net capital outflow and current account deficit is covered by net capital inflow (portfolio or FDI). Operationally, a surplus in the current account consists of net inflow of foreign currency, which is then purchased in the interbank market by a central bank (or a separate entity tasked with reserve management), increasing reserves. Those are almost never stored as cash and instead the reserve manager purchases financial assets denominated in foreign currency to ensure a positive return on reserves. Purchases of U.S. Treasury debt are counted as net capital inflow into the United States and are mirrored by a current 
account deficit, thereby making a full cycle. Since global imbalances are considered to be a relatively new phenomenon (before 2000 never exceeded $1 \%$ of world GDP as opposed to 2-2.5\% in 2006-2008), their impact on interest rates is limited to a specific time window. Their existence is perhaps best epitomized in "Greenspan's conundrum" (Greenspan, 2005) - insensitivity of long-term interest rates to changes in monetary policy stance in 2004-2006.

\section{The Case for "Emergency Measure"}

Opposed to the "new normal" conjecture is the view that QE has been an emergency measure, whose use was only justified by the depth and the severity of the 2007-2009 recession and the subsequent slow recovery in many countries. To paraphrase an old aphorism, "extraordinary circumstances call for extraordinary measures". There are widespread indications that this view is shared by the policymakers themselves.

\subsection{Great Recession was Different - Extraordinary Circumstances Call for Extraordinary Measures}

The case for QE being an emergency measure stems first and foremost from the fact that the 2007-2009 recession was unique in post-World War II history and should not be compared with other recessions. Its length and depth, international synchronization, negative impact on labour market and existence of severe financial distress all attest to the uniqueness of this recession (IMF, 2009).

The second pertains to the slow and uneven recovery after the recession, which was not anticipated by private and official forecasters, either. Compared to business cycle trough, GDP exceeded the pre-recession peak after 15 quarters in the U.S., 30 quarters in the EA, 22 quarters in the UK, 24 quarters in Japan and 9 quarters in Switzerland. Even so, GDP statistics paint an overly optimistic picture of the pace of the recovery, since key labour market variables (total employment, participation, employment and unemployment rates) have in some cases failed to return to pre-recession levels. Contribution of cyclical and structural factors in shaping these variables remains a hotly debated topic to this day, but the mere uncertainty regarding its nature was often a sufficient reason for central banks to continue to offer extraordinary amount of stimulus to afflicted economies.

Slow recovery can be considered a part of a broader suite of problems recognized in key developed economies after the GFC. These are: excessive debt burden (Lo \& Rogoff, 2015), persistent below-target inflation (IMF, 2013), low productivity growth (Gordon, 2012). For the most part, their impact on monetary policy is tangential or ambiguous (except for low inflation), but in the post-recession context their existence is not inconsequential for monetary policy. For instance, excessive debt burden increases the economy's sensitivity to interest rate changes and affects monetary policy transmission (Boivin, Kiley \& Mishkin, 2010), while low productivity growth dampens wage growth and reduces potential GDP growth. Finally, persistently low inflation impacts monetary policy considerations directly - lack of meaningful inflationary pressures has been cited as the paramount reason for maintaining expansionary monetary policy in most major economies throughout the 2009-2017 period.

\subsection{Asymmetry of Risks at the Zero Lower Bound}

The existence of zero lower bound (i.e. a minimum value for nominal short-term interest rates) has long been considered a potential problem for monetary policy (Summers, 1991; Fuhrer \& Madigan, 1997). By limiting the extent to which nominal interest rates can be reduced to near-zero levels (recent experience of Sweden, Switzerland, EA and Japan with negative interest rates suggests that the floor might be slightly negative), it also puts a limit on how low real interest rate can be pushed (assuming that inflation expectations remain anchored close to the central bank's inflation target). In ordinary recessions, this might not pose a problem, since real interest rate required to ensure the return of inflation to target is typically positive and easily achievable by standard monetary policy. Since 2009, many estimates of real interest rate implied by economic conditions in the Great Recession were provided. Most of them relied on some version of a Taylor rule, and the range of target rates consistent with observed inflation, output gap, unemployment or other variables often reached deeply negative levels. For instance, estimates for the U.S. indicate that real interest rate would have to fall to minus $5-8 \%$ in 2008 for monetary policy stance to 
remain consistent with macroeconomic fundamentals (Yellen, 2017). The ECB estimated that real interest rate would have to average $-2 \%$ in years 2009-2016 (Constancio, 2016).

The unique challenge posed by the existence of the zero lower bound implies that this is a situation central banks would rather avoid. Monetary policy decisions in such circumstances are associated with considerable uncertainty regarding the extent of economic slack, inflation outlook or the effectiveness of monetary policy. This warrants an asymmetric reaction function, in which monetary easing is more likely than monetary tightening (Adam \& Billi, 2006; Williams, 2009). In addition, the often-unspoken motivation to conduct monetary policy in such a fashion is to avoid the mistakes made by those central banks that tightened prematurely in the aftermath of the Great Recession and were forced to ease monetary policy to a greater extent than in 2008-2009. Examples of such banks include the ECB and the Sveriges Riksbank. It must be noted that this paragraph describes a realtime calculus conducted by central banks, one that might prove to be incorrect ex post. Excessive caution and asymmetric reaction functions can therefore lead to more monetary stimulus than warranted by economic conditions as known in hindsight.

\subsection{There is No Universal Trend in Interest Rates}

Opponents of "new normal" hypothesis often raise important objections to both the predictions of the hypothesis, and its premise. First, the downward trend in interest rates is not as universal as it is often claimed. Over the past decades there have been multiple examples of countries defying this pattern, exhibiting no apparent long-term trend in interest rates. The latest among those are Mexico, Russia and Brazil. Certainly, while each of one of these is a sizeable economy, neither has a central bank that meets the definition of major central bank by any margin. It is also true that each of these counterexamples refers to an emerging market (in financial market parlance), and not to a high-income economy (according to the World Bank's current list). However, all of the above are converging to the level of per capita income highly developed economies have and - given their population sizes - one should expect a sizeable (and increas- ing) economic complexity. Therefore, such economies, provided that the hypothesis of "new normal" is true, follow the same patterns as major developed economies have. The existence of such counterexamples implies at the very least that the secular demographic and macroeconomic trends can be trounced by other factors.

Second, trends in interest rates in different countries cannot be treated as independent, since bond yields are highly correlated and monetary policy decisions are interdependent. This is partly explained by the existence of common underlying trends in macroeconomic data and international synchronization of business cycles, but it must be remembered that different government bonds are substitutes for each other. To modify the Mundell-Flemming trilemma, in the world of free capital flows and flexible exchange rate, it is virtually impossible for one country's yield curve to behave in an independent fashion.

Furthermore, the existence of the downtrend in interest rates is also disputed. The main reason for scepticism here stems from the term structure of interest rates, namely, from the insight that real and nominal interest rates are a sum of several factors, not all of which are dependent on macroeconomic fundamentals. There various ways of decomposing long-term interest rates (Kim \& Wright, 2005; Adrian, Crump \& Moench, 2013), but all yield a similar outcome. The observed declines in long-term interest rates can be attributed to a large extent to a decline in various risk and term premia embedded in them. Reasons for the declines are certainly a subject for research in its own right, but it must be noted that the declines in longterm interest rate overstate the extent to which longterm expectations of real interest rates have declined over the years (Constancio, 2016).

Finally, focusing on 1980-2019 period ignores developments in interest rates that happened before. It can be argued (see e.g.) that choosing 1980 as a starting point for analysing trends in interest rates is misleading - interest rates had been rising since World War II until the turn of 1970s and 1980s, which marked their peak. When samples are extended into the first half of the 20th century or even earlier (Eichengreen, 2015), the apparent trend in real interest rates disappears and the long-term pattern is one of repeated uptrends and downtrends. Finally, the 
longest time series (see (Homer \& Sylla, 2005)) shows that nominal interest rates have been low throughout most of history.

\section{How Can this Dilemma be Solved in the Future?}

The two competing hypotheses cannot be easily tested with currently known macroeconomic data alone. One can, however, outline how macroeconomic variables would evolve under any of the two hypotheses.

The "new normal" hypothesis implies that the downtrends in short-term interest rates will be continued. Subsequent monetary tightening episodes will end at a lower terminal rate (therefore, short-term interest rates will peak lower and lower), while subsequent monetary easing episodes will bring interest rates lower - they will bottom at lower and lower levels. In addition, the use of quantitative easing as will continue in the future, as central banks will routinely employ it during future recessions.

The "emergency measure" hypothesis suggests that quantitative easing is unlikely to be used again in the future, as the extraordinary factors that influenced the use of unconventional monetary policy will cease to influence the economy and the overhang from the recession of 2007-2009 is gradually reduced. If this point of view is correct, the on-going economic expansion might be an unusually long one and interest rates might well return to or top pre-crisis levels. In addition, balance sheets will be "normalized", i.e. either allowed to decline in value, or actively reduced by selling securities currently held by central banks. The use of quantitative easing in the future is not impossible, but it is unlikely that the next recession will see the need for it. In such a world, the on-going (by some major central banks) monetary tightening will raise rates further and the next monetary easing will not return the short-term nominal interest rate back to zero.

Finally, it is important to note what would the preference for any of the two hypotheses mean for our knowledge of the economy and its underlying mechanisms? "New normal" describes a world, in which interest rates are ultimately determined by factors outside the reach of monetary policy. In such a world, monetary policy does not affect nominal variables over the long run. Regardless of what role would be given to the underlying factors, the world of low interest rates and quantitative easing is destiny for all economies. The second of the two views, one that sees $\mathrm{QE}$ as an emergency measure related to the severity of the 2007-2009 recession and the subsequent slow recovery, would imply that the central banker's standard model of the economy is true. In such a world, monetary policy does not affect real variables in the long run and the effectiveness of monetary policy in the short run is determined by the equilibrium real interest rate as well. It also implies that inflation expectations remain well-anchored. In addition, demographics and global factors are under these conditions - not the most important (or not universally dominant) drivers of interest rates.

It is probably too early to distinguish between the two worlds. However, the evolution of monetary policy globally brought several important clues. First, monetary policy normalization in the United States has (so far) been successful, but not complete. Assuming that the federal funds rate will not be raised again (as most market participants are at this time), short-term interest rates peaked at lower levels than in the previous episodes of monetary tightening in the U.S, just as the "new normal" hypothesis predicted. The Federal Reserve balance sheet unwind will also lock its security portfolio at higher sizes than before the crisis. Similar is the case of the Bank of England, whose monetary policy tightening has so far amounted to 50 bps, much less than the preceding easing (central banks of Norway or Canada likely fall into the same category). Second, even more extreme is the case of Japan and the euro area, where policy rates have not moved upward at all. Third, the low sensitivity of inflation to its standard macroeconomic determinants (unemployment gap, output gap) continues to be a source of uncertainty for policymakers (IMF, 2013). Persistence of low inflation is a global phenomenon, which suggests indirectly that current interest rate levels are not kept artificially too low (had that been the case, inflation would have been higher). Fourth, there is no evidence that the trends in interest rates described in the previous sections have been reversed. In particular, 10-year nominal interest rates are below their pre-crisis levels across the world 
and their predictability (using linear trends in 1, 3, 6 or 12-month horizon) was little changed in recent years. All in all, evidence in favor of the "new normal" hypothesis is accumulating.

\section{Summary}

This paper discussed the nature of quantitative easing and its role in central banks' toolkit. It began by describing the macroeconomic (theoretical and historical) context in which QE appeared and gained popularity as a monetary policy instrument. I then outlined two alternative hypotheses regarding the role of QE. The first is known as "new normal" and suggests that the use of $\mathrm{QE}$ is a pinnacle of longterm downward trend in nominal interest rates and decline in the standard instruments' potential effectiveness. Regardless of the nature of such trends - I discussed several explanations (demography, globalization and global imbalances) - they imply that central banks in developed economies are and will be increasingly less able to stimulate the economy using short-term interest rates alone. A competitive explanation suggests that quantitative easing is an emergency measure, justified by the depth of the 2007-2009 recession and the disappointing pace of the subsequent recovery. I also report arguments raised by the proponents of the latter hypothesis against the former. Finally, I outline how the future evolution of key macroeconomic variables would invalidate either hypothesis. In particular, the course of the business cycle, in particular the length of the current expansion, terminal short-term interest rates at their next peaks, must be carefully watched. In this context, the evolution of monetary policy of major central banks points to the former hypothesis being more likely. Therefore, barring unexpected breaks in longterm macroeconomic trends and convergence, it is prudent that central banks in lower-income countries (such as Poland in this context) prepare for the eventual need to employ unconventional monetary policy tools (with particular emphasis on QE as the most popular instrument).

\section{References}

Abu, N. (2017). Does Okun's law exist in Nigeria? Evidence from ARDL bounds testing approach. Contemporary Economics, 11(2), 131-144.
Abu, N. (2019). Inflation and unemployment trade-off: A re-examination of the Phillips curve and its stability in Nigeria. Contemporary Economics, 13(1), 21-34.

Abu, N., \& Staniewski, M. W. (2019). Determinants of corruption in Nigeria: Evidence from various estimation techniques. Economic Research-Ekonomska Istraživanja, 32(1), 3052-3076.

Ahmad, A. H., Aworinde, O. B., \& Martin, C. (2015). Threshold cointegration and the short-run dynamics of twin deficit hypothesis in African countries. Journal of Economic Asymmetries, 12, 80-91.

Ahmed, S. M., \& Ansari, M. I. (1994). A tale of two deficits: An empirical investigation for Canada. International Trade Journal, 8(4), 483-503.

Alhassan, A. L., \& Fiador, V. (2014). Insurance-growth nexus in Ghana: An autoregressive distributed lag bounds cointegration approach. Review of Development Finance, 4(2), 83-96.

Aloryito, G. K., Senadza, B., \& Nketiah-Amponsah, E. (2016). Testing the twin deficits hypothesis: Effect of fiscal balance on current account balanceA panel analysis of Sub-Saharan Africa. Modern Economy, 7, 945-954.

Alse, J., \& Bahmani-Oskooee, M. (1992). Are the twin deficits really related? A comment. Contemporary Policy Issues, 10, 108-111.

Anoruo, E., \& Ramchander, S. (1998). Current account and fiscal deficits: Evidence from five developing economies of Asia. Journal of Asian Economics, 9(3), 487-501.

Aqeel, A., \& Nishat, M. (2000). The twin deficits phenomenon: Evidence from Pakistan. Pakistan Development Review, 39(4), 535-550.

Aristovnik, A. (2008). Short-term determinants of current account deficits: Evidence from Eastern Europe and the former Soviet Union. Eastern European Economics, 46(1), 24-42.

Aristovnik, A., \& Djurić, S. (2010). Twin deficits and the Feldstein-Horioka puzzle: A comparison of the EU member states and candidate countries. MPRA Paper, 24149.

Arora, H. K., \& Dua, P. (1993). Budget deficits, domestic investment and trade deficits.Contemporary Policy Issues, 11, 29-44.

Aslan, M., Buyrukoglu, S., Oz, E., \& Nazlioglu, S. (2014). Does fiscal policy matter for trade balance in the OECD countries? Panel vector error correction estimation. International Journal of Trade and Global Markets, 7(4), 271-284.

Bachman, D. D. (1992). Why is the U.S current account deficit so large? Evidence from vector autoregres- 
sions.Southern Economic Journal, 59(2), 232-240.

Baharumshah, A. Z., Lau, E., \& Khalid, A. M. (2006). Testing twin deficits hypothesis using VARs and variance decomposition. Journal of the Asia Pacific Economy, 11(3), 331-354.

Baharumshah, A. Z., \& Lau, E. (2007). Dynamics of fiscal and current account deficits in Thailand: An empirical investigation. Journal of Economic Studies, 34(6), 454-475.

Baharumshah, A. Z., \& Lau, E. (2009). Structural breaks and the twin deficits hypothesis: Evidence from East Asian countries. Economics Bulletin, 29(4), 1-7.

Banday, U. J., \& Aneja, R. (2018). Does fiscal deficit affect current account deficit in India? An econometric analysis. Review of Market Integration, 9(3) $1-20$.

Basu, S., \& Datta, D. (2005). Does fiscal deficit influence trade deficit?: An econometric enquiry. Economic and Political Weekly, 40(30), 3311-3318.

Bayraktar, Y., Egri, T., \& Yildiz, F. (2016). A causal relationship between oil prices, current account deficit, and economic growth: An empirical analysis from fragile five countries. Ecoforum Journal, 5(3), 29-44.

Besel, F. (2017). Oil prices affect current account deficit: Empirical evidence From Turkey. Journal of Applied Research in Finance and Economics, 3(2), 13-21.

Bluedorn, J., \& Leigh, D. (2011). Revisiting the twin deficits hypothesis: The effect of fiscal consolidation on the current account.IMF Economic Review, $59,582-602$.

Bollano, J., \& Ibrahimaj, D. (2015). Current account determinants in Central and Eastern European Countries. Graduate Institute of International and Development Studies Working Paper, 22/2015.

Calderón, C., Chong, A., \& Loayza, N. (2000). Determinants of current account deficits in developing countries. Policy Research Working Paper, 2398.

Cavdar, S. C., \& Aydin, A. D. (2015). Understanding the factors behind current account deficit problem: A panel logit approach on 16 OECD member countries. Procedia Economics and Finance, 30, 187-194.

Chen, Y., \& Liu, D. (2018). Government spending shocks and the real exchange rate in China: Evidence from a sign-restricted VAR model. Economic Modelling, 68, 543-554.

Chinn, M. D., \& Prasad, E. S. (2003). Medium-term determinants of current accounts in industrial and developing countries: An empirical exploration. Journal of International Economics, 59(1), 47-76.
Daly, V., \& Siddiki, J. U. (2009). The twin deficits in OECD countries: Cointegration analysis with regime shifts. Applied Economics Letters, 16(11), 1155-1164.

Dickey, D. A., \& Fuller, W. A. (1979). Distribution of the estimators for autoregressive time series with a unit root. Journal of the American statistical association, 74(366a), 427-431.

Enders, W., \& Lee, B-S. (1990). Current account and budget deficits: Twins or distant cousins? Review of Economics and Statistics, 72(3), 373-381.

Engle, R. F., \& Granger, C. J. (1987). Cointegration and error-correction - Representation, estimation and testing. Econometrica, 55(2), 251-278.

Forte, F., \& Magazzino, C. (2013). Twin deficits in the European countries. International Advances in Economic Research, 19(3), 289-310.

Goyal, A., \& Kumar, A. (2018). The effect of oil shocks and cyclicality in hiding Indian twin deficits. Journal of Economic Studies, 45(1), 27-45.

Granger, C. W. J. (1986). Development in the study of cointegrated economic variables. Oxford Bulletin of Economics and Statistics, 48(3), 213-228.

Greene, W. (2003). Econometric Analysis. $5^{\text {th }}$ ed. New Jersey: Prentice Hall.

Grier, K., \& Ye, H. (2009). Twin sons of different mothers: The long and short of the twin deficits debate. Economic Inquiry, 47(4), 625-638.

Hatemi-J, A.,\& Shukur, G. (2002). Multivariatebased causality tests of twin deficits in the US. Journal of Applied Statistics, 29(6), 817-824.

Helmy, H. E. (2018). The twin deficit hypothesis in Egypt. Journal of Policy Modeling, 4(2), 328-349.

Huntington, H. G. (2015). Crude oil trade and current account deficits. Energy Economics, 50, 70-79.

Idil, U. Z. (2010). Determinants of current account: The relationship between internal and external balances in Turkey. Applied Econometrics and International Development, 10(2), 115-126.

Islam, M. F. (1998). Brazil's twin deficits: An empirical examination. Atlantic Economic Journal, 26(2), 121-128.

Johansen, S. (1988). Statistical analysis of cointegration vectors. Journal of Economic Dynamics and Control, 12(2-3), 231-254.

Johansen, S. (1991). Estimation and hypothesis testing of cointegration vectors in Gaussian vector autoregressive models. Econometrica, 59(6), 1551-1580.

Johansen, S., \& Juselius, K. (1990). Maximum likelihood estimation and inference on cointegration - With applications to the demand for money. Oxford Bulletin of Economics and Statistics, 52(2), 
169-210.

Kalou, S., \& Paleologou, S. (2012). The twin deficits hypothesis: Revisiting an EMU country. Journal of Policy Modeling, 34, 230-241.

Katircioglu, S. T., Fethi, S., \& Fethi, M. D. (2009). Twin deficits phenomenon in small islands: An empirical investigation by panel data analysis. Applied Economics Letters, 16(15), 1569-1573.

Khalid, A. M., \& Guan, T. W. (1999). Causality tests of budget and current account deficits: Cross-country comparisons. Empirical Economics, 24, 389-402.

Kiran, B. (2011). On the twin deficits hypothesis: Evidence from Turkey. Applied Econometrics and International Development, 11(1), 59-66.

Kouassi, E., Mougoué, M., \& Kymn, K. O. (2004). Causality tests of the relationship between the twin deficits. Empirical Economics, 29,503-525.

Kumar, P. S. (2016). Twin deficit hypothesis: Some recent evidence from India. Global Business and Economics Review, 18(3-4), 487-495.

Lau, E., \& Baharumshah, A. Z. (2004). On the twin deficits hypothesis: Is Malysia different? Pertanika Journal of Social Sciences and Humanities, 12(2), 87-100.

Lau, E., \& Baharumshah, A. Z. (2006). Twin deficits hypothesis in SEACEN countries: A panel data analysis of relationship between public budget and current account deficits. Applied Econometrics and International Development, 6(2), 213-226.

Lau, E., Mansor, S. A., \& Puah, C-H. (2010). Revival of the twin deficits in Asian crisis affected countries. Economic Issues, 15(1), 29-53.

Leachman, L. L., \& Francis, B. (2002). Twin deficits: Apparition or reality?. Applied Economics, 34(9), 1121-1132.

Liew, V. K-S. (2004). Which lag length selection criteria should we employ? Economics Bulletin, 3(33), 1-9.

Lutkepohl, H. (1991). Introduction to Multiple Time Series Analysis. Springer-Verlag, Germany.

Magazzino, C. (2017). Twin deficits or Ricardian Equivalence? Empirical evidence in the APEC countries. Asian Economic and Financial Review, 7(10), 959-971.

Marinheiro, C. F. (2008). Ricardian equivalence, twin deficits, and the Feldstein-Horioka puzzle in Egypt. Journal of Policy Modeling, 30, 1041-1056.

Montalvo, J. G. (1995). Comparing cointegrating regression estimators: Some additional Monte Carlo results. Economics Letters, 48, 229-234.

Mukhtar, T., Zakaria, M., \& Ahmed, M. (2007). An empirical investigation for the twin deficits hypothesis in Pakistan. Journal of Economic Cooperation and Development, 28(4), 63-80.

Mumtaz, K., \& Munir, K. (2016). Dynamics of twin deficits in South Asian countries. MPRA Paper, 74592.

Musau, A., \& Veka, S. (2018). Crude oil trade and current account deficits: Replication and extension. Empirical Economics, 1-23.

Nadenichek, J. (2016). A cross-country test of Ricardian Equivalence and the twin deficits hypothesis. International Journal of Applied Economics, 13(1), 32-42.

Narayan, S., \& Narayan, P. K. (2004). Determinants of demand for Fiji's exports: An empirical investigation. Developing Economies, 42(1), 95-112.

Onafowora, O. A., \& Owoye, O. (2006). An empirical investigation of budget and trade deficits: The case of Nigeria. Journal of Developing Areas, 39(2), 153 174.

Özata, E. (2014). Sustainability of current account deficit with high oil prices: Evidence from Turkey. International Journal of Economic Sciences, 3(2). 71-88.

Ozturk, I., \& Acaravci, A. (2010). The causal relationship between energy consumption and GDP in Albania, Bulgaria, Hungary and Romania: Evidence from ARDL bounds testing approach. Applied Energy, 87(6), 1938-1943.

Ozturk, I., \& Acaravci, A. (2011). Electricity consumption and real GDP causality nexus: Evidence from ARDL bounds testing approach for 11 MENA countries. Applied Energy, 88(8), 2885-2892.

Paparas, D., Richter, C., \& Mu, H. (2016). An econometric analysis of the twin deficits hypothesis in Greece during the period 1960-2014. Applied Economics Quarterly, 62(4), 341-360.

Pattichis, C. (2004). Budget and trade deficits in Lebanon. Applied Economics Letters, 11(2), 105-108.

Pelagidis, T., \& Desli, E. (2004). Deficits, growth and the current slowdown: What role for fiscal policy?. Journal of Post Keynesian Economics, 26(3), 461469.

Pesaran, H. M., \& Shin, Y. (1999). Autoregressive distributed lag modelling approach to cointegration analysis. In: Storm, S. Editor. econometrics and economic theory in the $20^{\text {th }}$ century; The Ragnar Frisch centennial symposium. Cambridge University Press, (chapter 11).

Pesaran, M. H., Shin, Y., \& Smith R. J. (2001). Bounds testing approaches to the analysis of level relationships. Journal of Applied Econometrics, 16, 289-326.

Phillips, P. C., \& Perron, P. (1988). Testing for a unit root in time series regression. Biometrika, 75(2), 
335-346.

Piersanti, G. (2000). Current account dynamics and expected future budget deficits: Some international evidence. Journal of International Money and Finance, 19, 255-271.

Ravinthirakumaran, N., Selvanathan, S., \& Selvanathan, E. A. (2016). The twin deficits hypothesis in the SAARC countries: An empirical investigation. Journal of the Asia Pacific Economy, 21(1), 77-90.

Raza, S. A., \& Jawaid, S. T. (2014). Foreign capital inflows, economic growth and stock market capitalization in Asian countries: An ARDL bound testing approach. Quality \& Quantity, 48(1), 375385.

Rosensweig, J. A., \& Tallman, E. W. (1993). Fiscal policy and trade adjustment: Are the deficits really twins?. Economic Inquiry, 31(4), 580-594.

Saikkonen, P. (1992). Estimation and testing of cointegrated systems by an autoregressive approximation. Econometric Theory, 8(1), 1-27.

Saleh, A. S., Nair, M., \& Agalewatte, T. (2005). The twin deficits problem in Sri Lanka: An econometric analysis. South Asia Economic Journal, 6(2), 221239.

Salvatore, D. (2006). Twin deficits in the G-7 countries and global structural imbalances. Journal of Policy Modeling, 28, 701-712.

Şen, H., \& Kaya, A. (2016). Are the twin or triple deficits hypotheses applicable to post-communist countries?. BOFIT Discussion Papers, 3/2016.

Şen, A., Senturk, M., Sancar, C., \& Akbas, Y. E. (2014). Empirical findings on triplet deficits hypothesis: The case of Turkey. Journal of Economic Cooperation and Development, 35(1), 81-102.

Singh, T. (2015). Trade openness and economic growth in Canada: An evidence from time-series tests. Global Economy Journal, 15(3), 361-407.

Soukiazis E., Antunes, M., \& Kostakis, I. (2017). The Greek economy under the twin-deficit pressure: A demand orientated growth approach. International Review of Applied Economics, 32(2), 215-236.

Soukiazis, E., Cerqueira P. A., \& Antunes, M. (2015). Causes of the decline of economic growth in Italy with special reference to the post-euro period: A balance-of-payments approach. Review of Keynesian Economics, 3(4), 491-516.

Stock, J. H., \& Watson, M. W. (1993). A simple estimator of cointegrating vectors in higher order integrated systems. Econometrica, 61(4), 783-820.

Tang, C. F. (2015). General equilibrium perspective on twin deficits hypothesis: An empirical study with
US results. Global Economic Review, 44(2), 184201.

Tang, C. F., \& Lean, H. H. (2007a). Will inflation increase crime rate? New Evidence from bounds and modified Wald tests. Global Crime, 8(4), 311-323.

Tang, C. F., \& Lean, H. H. (2007b). Is Phillips curve stable in Malaysia? New empirical evidence. $\mathrm{Ma}$ laysian Journal of Economic Studies, 44(2), 95-105.

Toda, H. Y., \& Yamamoto, T. (1995). Statistical inferences in vector auto-regressions with possibly integrated processes. Journal of Econometrics, 66(1), 225-250.

Tosun, M. U., Iyidogan, P. V., \& Telatar, E. (2014). The twin deficits in selected Central and Eastern European economies: Bounds testing approach with causality analysis. Romanian Journal of Economic Forecasting, XVII(2), 141-160.

Trachanas, E., \& Katrakilidis, C. (2013). The dynamic linkages of fiscal and current account deficits: New evidence from five highly indebted European countries accounting for regime shifts and asymmetries. Economic Modelling, 31, 502-510.

Ucal, H., \& Bolukbas, M. (2013). The role of twin deficits in sustainable growth: An econometric analysis for Turkey. Journal of Economic and Social Studies, 3(2), 39-51.

Vamvoukas, G. A. (1999). The twin deficits phenomenon: Evidence from Greece. Applied Economics, 31(9), 1093-1100.

Vlahinic, N., \& Jakovac, P. (2014). Revisiting the energy consumption-growth nexus for Croatia: New evidence from a multivariate framework analysis. Contemporary Economics, 8(4), 435-452.

Xie, Z., \& Chen, S-W. (2014). Untangling the causal relationship between government budget and current account deficits in OECD countries: Evidence from bootstrap panel Granger causality. International Review of Economics and Finance, 31, 95104.

Zapata, H. O., \& Rimbaldi, A. N. (1997). Monte Carlo evidence on cointegration and causation. Oxford Bulletin of Economics and Statistics, 59(2), 285-298 